\title{
A GENRE ANALYSIS OF PROMOTIONAL TEXTS IN AN INDONESIAN BATIK INDUSTRY
}

\author{
Diah Kristina' \\ Noor Hashima ${ }^{2}$ \\ Hariharan ${ }^{3}$ \\ Universitas Sebelas Maret of Surakarta, Indonesia' \\ Universiti Utara Malaysia ${ }^{2,3}$ \\ kristina_diah@yahoo.com
}

First received: 30 September 2016

Final proof received: 28 September 2017

\begin{abstract}
This study explored sales promotion letters (SPLs) and company profiles (CPs) of two prominent batik companies in Solo, Central Java, Indonesia. This essay draws its data from the most important primary source of information on sales promotion letters and company profiles namely words, phrases, and clauses taken from the SPLs and CPs of batik written in Indonesian. Secondary sources were also consulted in this research, among these transcribed data obtained from in-depth interviews with the text writers and buyers. Three SPLs and two batik CPs were analyzed. In addition, two informants (marketing and promotion managers) typifying the text production perspective and two buyers typifying the text consumption perspective were interviewed. This research was guided by theories of genre analysis which focuses on patterns of rhetorical organization and genre-specific language features. This study employed the multi-dimensional and multi perspective model of analysis focusing on textual, socio-cognitive and ethnographic aspects of the texts. This study concludes that the strong Javanese cultural influence has made the underlying intention of gaining profits to be less explicitly stated. Secondly, the textual analysis and the in-depth interviews supported the view that CPs of batik had been ideally used to create a favorable image of the company. Thirdly, the most distinctive feature that differentiated establishing credentials in the Indonesian batik business context had been the utilization of a sense of moral obligation to preserve native culture. Fourthly, the chemistry between writers and readers of SPLs and CPs built a strong foundation for mutual understanding and thus paved the way for making purchases. To conclude, this study has shown how the wider culture and the culture of the discourse community has contributed to the framing and formatting of SPLs and CPs of batik in terms of lexico-grammar, cognitive structuring, intertextuality and interdiscursivity.
\end{abstract}

Keyword: genre analysis; promotional texts; batik industry

In modern Indonesian business, printed promotional material serves as one of the most important initial means of formal business communication between the producers and future domestic buyers. In the context of batik industries, printed promotional tools may consist of leaflets, catalogues, flyers, bulletins, press releases, advertorials and company profiles. Leaflets, flyers, catalogues, printed and electronic advertisements are recognized to be more visually dominant business documents whereas company profiles, advertorials, bulletins, press releases, and sales promotion letters are more language-dominant in their orientation.

Recently studies of the genre and move analyses have been discussed in popular scientific texts (Lieungnapar, Todd, \& Trakulkasemsuk, 2017), rhetorical composition of pedagogy and research articles (Cotos, Huffman, \& Link, 2017), moves in science writing of student laboratory report (Parkinson, 2017), and move analysis on abstracts of research articles (Jiang \& Hyland, 2017).

Sales promotion letters (SPLs) and company profiles (CPs) are promotional documents used in the formal batik business contexts. SPL is an unsolicited letter addressed to potential buyers to purchase a product or service. The letter aims at capturing the attention, sustaining the interest of potential buyers and convincing them of the gains or values of the promoted products (Bhatia, 1993). CP usually provides detailed information as well as an evaluation of the products to promote the image of the batik company.

Considering the strong influence of feudalism and aristocratic lifestyle of the Javanese community (Geertz, 1973), the ways in which batik products are promoted need to be thoroughly examined. Berkenkotter and Huckin (1995) argue that genre conventions signal the norms and ideologies of a discourse community. Likewise, Grabe and Kaplan (1996) pointed out that knowledge is understood to be the creation of discourse communities.

\section{Conceptual Framework}

In this study, the applied genre analysis is informed by the multi-dimensional and multi-perspective model proposed by Bhatia (2004). Jaworski and Coupland (1999) assert that 'multiple-perspectives 
and methods increase the likelihood of reaching good explanations' (p. 37). The multi-perspective model employs textual and socio-cognitive aspects, incorporates tactical and professional, ethnographical and socio-critical spaces in its analytical model. Leitch and Palmer (2010) define space as the physical setting or location in which the text occurs.

To construct a model of analytical procedures for investigating genres in the world of discourse, we need to examine the textual space, which encompasses the use of text-internal features, principally the values they carry in the context of rhetorical moves, discourse strategies, regularities of organization, intertextuality and several aspects of interdiscursivity. In this study, the discourse patterning or moves was identified by inferences based on the content of the text and the linguistic clues. Linguistically, the meanings are realized in formulaic expressions, specific lexical items and cohesive markers. Additionally, the moves were explored in terms of their positioning, obligatory, optional and iterative order.

The socio-cognitive space or the discourse patterning as the second perspective, accounts for the participants' relationships within the batik industries and their contributions to the process of genre construction, interpretation, use and exploitation in the context of batik professional practices and other institutional practices and constraints. The socio-cognitive analysis was done by conducting grounded and ethnographic investigations of batik professional practices. These aspects of investigation, in Bhatia's (2004) view should consider the way expert users of language exploit and manipulate generic resources to create hybrid genres, which may include mixing, embedding, bending and appropriating of generic resources.

The socio-cognitive space that incorporates the tactical and professional implications presented by Bhatia (2004) is close to that of Berkenkotter and Huckin's (1995) 'duality of structure'. Duality of structure refers to the view that though professional genres constitute social structures in professional, institutional, and organizational contexts, every author of a professional genre also has an individual structure reflecting individual creativity, freedom, and intention and strategies. Nevertheless, the authors should also conform to the constraints imposed by the community of a specific genre.

Figure 1 presents the model of Bhatia's study, which focuses on the textual and the socio-cognitive spaces. To analyze the textual space, the researcher deconstructed the texts to investigate the use of lexico-grammatical and rhetorical resources. In this analysis, the texts were explored in terms of their generic conventions to address issues such as features of the discourse and the structuring of the discourse (Bhatia, 2004). To examine the sociocognitive space the researcher scrutinized CP texts and SPLs in order to consider the genre construction procedures as well as the audience reception procedures and insights. Additionally, the researcher analyzed rhetorical strategies and appropriation of generic resources to respond to familiar and novel components in the SPLs and CPs of batik.

Spaces or
Perspectives
Textual
Socio-cognitive
(Tactical \&
procedures Professional)
Ethnographic

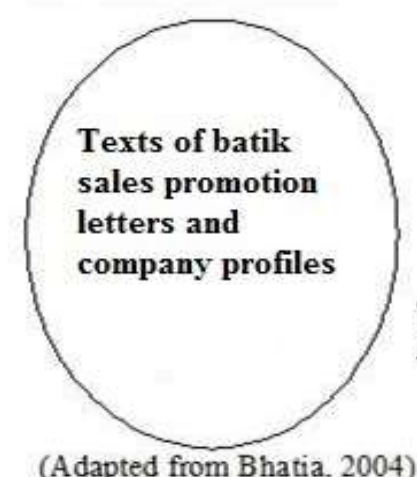

Focus of Analysis

Lexico-grammatical and Discoursal resources

Genre construction procedures Audience reception procedures

Textography of discourse practices Accounts of recipients of genres

Figure 1. Model of this study spaces of focus of analysis perspectives (adapted from Bhatia, 2004)

Observing genres beyond the textual organizations is useful in terms of appraising the typical patterns in composing processes, reading practices, and social roles of participants (Pare \& Smart, 1994).

The CPs and SPLs are constructions of the professional community in which the meaning is created by and for the consumption of members of the professional community in Indonesia.
Consequently, any meaningful understanding of the texts must be informed by the perceptions and practices of this particular professional community or the emic's (insider's) perspectives (Lillis, 2008).

\section{METHOD}

The discussed methodology concentrates on two significant issues, data collection and data analysis. 


\section{Data collection}

This essay draws its data from the most important primary source of information on sales promotion letters and company profiles consisting of words, phrases, and clauses taken from the SPLs and CPs of batik written in Indonesian. Transcribed data obtained from in-depth interviews with the texts producers of the two prominent batik industries and two future buyers were the secondary source of data.

Interviews were conducted with two sales and marketing managers and two buyers. The sales and marketing managers were selected as they were considered the most knowledgeable resource persons in the sales and promotion field. The buyers were selected as informants because they bought batik products in large numbers and were also considered the prominent decision makers in the subject matter in their respective offices. The first informant was the head of the procurement department of a national telecommunication branch office based in Solo. He acquired 400 pieces of blouses and shirts. The second informant, the head of the Blora Local Ministry of Tourism, purchased more than 10,000 pieces of batik cloth.

This research was conducted in Solo, Central Java, Indonesia, since this city is both the biggest and oldest batik producer in Indonesia. Batik is the Indonesian icon while Solo is recognized to be the design and motif icon for batik. The BS and BDH were selected as they had high reputation and long experience in batik making. BDH was founded in 1967 and BS in 1947. In terms of market share, $\mathrm{BDH}$ sold $90 \%$ of its products to the domestic dealers and $10 \%$ to the overseas market while BS had the same stance as well in terms of their overseas market share. For domestic selling purposes, these batik manufacturers relied on representative stores and outlets. However, for export purposes, to a certain extent, they employed intermediaries such as 'A. B.' for large online business transactions.

\section{Data analysis}

Data analysis was based on three main research questions: (1) How were meanings realized through the grammatical and rhetorical resources available in the batik company profile texts and sales promotion letters? (2) How were the two business documents rhetorically structured in terms of motives, attitudes and values? (3) How were the relationships built between communicative purposes of the genre and the moves identified?

To explicate the way meanings were realized in the CP and SPL texts, this study employed a genre analysis approach in which the rhetorical structures or features and the communicative purposes of those business texts were examined. Rhetorical feature here refers to the organization of ideas (moves) in a specific text or segment of a text and the textual features of the text are based on an analysis of the semantic or communicative units of the text (Refer to Figure 1).

\section{Language analysis framework}

Figure 2 presents the process of analyzing the language of the CP texts and SPLs as a finished product. The language in the CP texts and SPLs reflects professional activities, professional and institutional constraints, concerns or interests and the culture of the related organization. According to Leki (1991), contrastive rhetorical researchers should view writing products as equally important as writing processes, and context as the view adopted in genre analysis studies. He believes that examining only text performance without considering the writing context can be misleading.

Devitt (1993:581) on the other hand argues that understanding writing as product means 'understanding more deeply of the goals of the writer and the forces at work in its generation and regeneration'. In contrast, understanding writing as process refers to 'understanding generic goals (the historical community and rhetorical forces that shape them), how the writer learns them and how the writer uses them'.

Considering Leki's (1991) view on the weaknesses of analyzing texts as finished products, the researcher conducted in-depth interviews with the writers in their professional routines to deconstruct how the writers of CP and SPL texts performed their jobs. The exploration includes the following issues:

- How important are the SPL and CP texts to the company?

- What would the writers include in these two business texts?

In depth interviews with the potential buyers were then conducted to analyze the effectiveness of the promotional texts. The following issues were explored:

- How effective are the CP texts and SPLs in motivating the potential buyers to conduct business with the batik producers?

- Do the CP texts and SPLs fulfill the buyers' expectations?

- What do the buyers expect to find in a $\mathrm{CP}$ text and a SPL?

The in-depth interviews provided a more balanced result in the analysis of the texts from both the production as well as the consumption perspectives. In terms of the significance of a mutual relationship between the audience and writer of a document, Grabe and Kaplan (1996) believe that audience, purpose, and topic shape writing. Considering the role of audience as back-grounding schemata in the writing process, understanding how the writers of the business documents construct their discourses is therefore crucial. The importance of the audience in business prose is stressed by Seltzer 
and Sherwin (1989:4), who states that 'audience probably matters more than anything when a good writer orders business prose'. Another aspect that was considered in the framework of this study was the institutional business culture under the more cultural specific situation of Solo, including their ways of promoting batik products in Indonesian language.

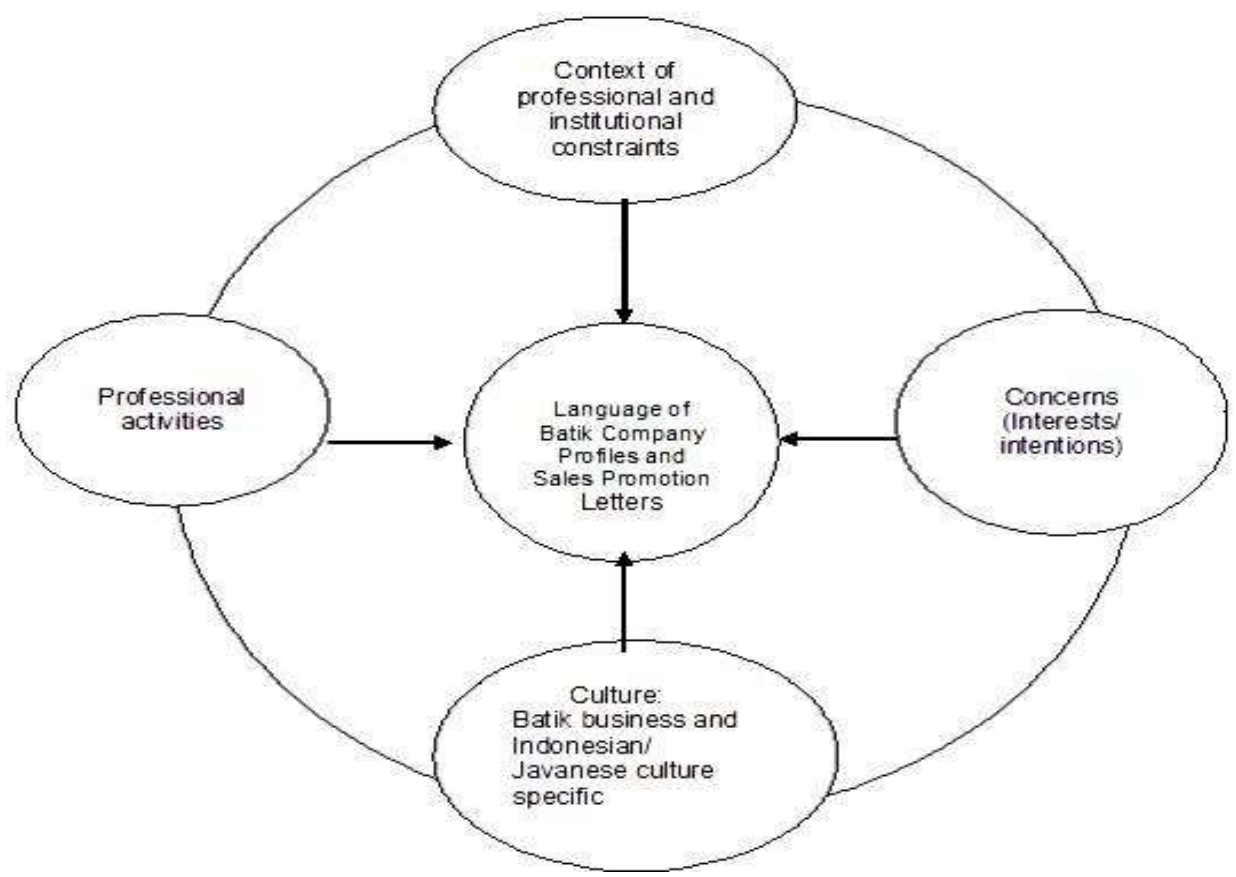

Figure 2. Language analysis framework

In terms of textual analysis, the identification of the communicative units or moves and their subsequent elements or steps, involves subjective judgment. The element of subjectivity can be reduced by inter-rater validity technique (Safnil, 2000). The double-checking system employed in this study was informed by Jolivet and Thomas (2005:49), who claim that move analysis needs a 'dual rating system'. It means that agreements of the two analysts are reached on the segmentation of the moves.

Two CPs and three SPLs written in Indonesian were first translated into English and then verified by a lecturer majoring in translation. In terms of the translation checking, only a difference of $2-5 \%$ was found. Similarly, the moves analysis was double-checked by a lecturer majoring in Indonesian discourse analysis. In relation to the identification of the moves and steps in the texts, the inter-rater difference was between $5-10 \%$.

In qualitative research, reliability refers to the identification whether 'the findings obtained are consistent with the data collected' (Merriam, 2002, p. 206). Three techniques were used in this study to ensure reliability namely, the investigator's position, audit trail, and triangulation. The researcher explains her assumptions and background theories in this study, her position vis-à-vis the group being studied, the criteria for selecting informants and a description of them, and the social context of data collection. The researcher also describes the data collection, and data classification in detail and how decisions were made throughout the research. Then the researcher triangulated the textual data of SPLs and CPs of batik and interview data from the sales and promotion managers and buyers of batik production.

\section{RESULTS AND DISCUSSION}

Structurally, the SPLs of batik have five sequential rhetorical moves starting from (1) introducing the offer that comprises two steps namely (a) offering products and (b) essential detailing of the products; (2) preclosing; (3) eliciting interest; (4) soliciting response, and terminated by (5) ending politely.

Linguistically, the step of offering batik products is displayed through the following formulaic expressions:
(1) Dengan ini kami sampaikan penawaran...(BS/SPL/1)
(2) Dengan ini kami mengajukan penawaran...(BS/SPL/2)
(3) Dengan ini kami menyampaikan penawaran... (BS/SPL/3)
(We are pleased to offer)

The three expressions share the same meaning, that is, 'we are pleased to offer'. Variation in terms of choice of lexis takes the form of sampaikan, mengajukan, and menyampaikan. In terms of cohesive marker, dengan ini in Indonesian has been employed widely to highlight the beginning of a letter. On the other hand, the step essential detailing 
of the products is realized by the following formulaic expressions:

(1) Dengan syarat dan ketentuan sebagai berikut...(BS/SPL/1)

(2) Dengan ketentuan dan penjelasan sebagai berikut...(BS/SPL/2)

(3) Dengan ketentuan sebagai berikut...(BS/SPL/3) (With the following requirements)

The lexis in the step of essential detailing of the products covers syarat dan ketentuan, which are synonymous and mean requirements.

The next rhetorical move after introducing the offer is preclosing. The typical expression to signal a preclosing in any Indonesian text, both written and oral, is the use of the cohesive marker word demikian.

(1) Demikian penawaran yang kami sampaikan (BS/SPL/1,2,3).

(That is our offer)

Indirectness has been the core issue in the sales promotion letters of batik companies, especially for eliciting response. Instead of disclosing openly the intention of changing the potential buyers' behavior into one that favors the seller, the writer seems to prefer employing a less direct persuasion. The formulaic expression employed across the data is as follows:

(2) Semoga dapat menjadikan bahan pertimbangan (BS/SPL/1,2,3)

(We do hope that this offer will be taken into consideration).

The subsequent move is soliciting response. This move in the sales promotion of batik tends to elicit future buyers to contact the seller for a more promising business collaboration. The significance of this move in the selling effort has been highlighted by Bhatia (1993) and Limaye (1984). The specific expressions used were:

(1) Bilamana ada penjelasan yang kurang jelas, mohon menghubungi kami kembali (BS/SPL/1)

(2) Bila ada yang kurang jelas dalam penawaran ini dapat ditanyakan kepada kami (BS/SPL/2,3) (For any queries, do not hesitate to contact us)

The two afore-mentioned expressions can be used simultaneously with another expression:

(3) Kami menantikan kabar baik dari ibu/bapak (BS/SPL/1)

(We are waiting for the good news from you)

The last stage of batik SPLs is ending politely. This rhetorical move seems to be universally applied in English and Indonesian SPLs alike. However, the Indonesian version, especially the batik SPL, makes use of amore straight-forward and less motivating end.

(1) Sebelumnya kami ucapkan terimakasih atas perhatian yang diberikan (BS/SPL/1). (And we are deeply grateful for your attention)

(2) Atas perhatian yang diberikan kami ucapkan terimakasih (BS/SPL/2, 3).
(Thank you for your attention)

The most important issue about SPLs of batik compared to that of earlier works like Bhatia's (1993) is the move of establishing credentials. Bhatia suggested that establishing credentials is a move used to show that a company is capable to fulfill the needs of the potential customers and is the best. In these SPLs of batik, establishing credentials does not exist because the readers of the sales letters are already familiar with the batik companies. An SPL of batik is usually sent to an inclined or half inclined potential buyer.

Additionally, instead of employing pressure tactics such as those as utilized in English SPLs (Barron, 2006; Bhatia, 1993; Cheung, 2006), SPLs of batik refrain from using these; rather they employ a soliciting response which is culturally more acceptable. Table 1 displays the moves in SPLs in the English in contrast to those in the Indonesian language.

Socio-cognitive structures, or discourse patterning of a genre has specific conventions. Convention refers to the determiner of staging the sections of a document (Seltzer \& Sherwin, 1989). Contrary to the established convention of the sevenmove model in the English SPLs advocated by Bhatia (1993), batik SPLs written in Indonesian are limited to five moves instead. The Indonesian version of batik SPLs has five rhetorical moves ranging from (1) introducing the offer, which covers (a) offering product and (b) detailing of the offer, (2) pre-closing, (3) eliciting interest, (4) soliciting response, and (5) ending politely.

The five-move model of batik SPLs in Indonesian excludes the following moves: establishing credentials, offering incentives, enclosing documents, and using pressure tactics, a series of moves associated with the established version of English sales promotion letters. Among the moves excluded, the moves of establishing credentials, offering incentives, and using pressure tactics need to be discussed thoroughly.

Establishing credentials has been widely considered uncommon in the Indonesian SPLs of batik. The idea of highlighting the needs of the potential customer and the claim that the company is the most appropriate one to fulfill the needs (Bhatia, 1993) had already been addressed in the informal meeting between the seller and the prospective buyer before any written correspondence. The potential buyers are familiar with the good reputation of the company and its products, prior to the decision of purchase was made. The working assumption is that the better the reputation of the batik company and the more familiar the potential customers with the batik company, the bigger the opportunity of purchase would be since the schemata of highly reputable batik company has already been in the mind of these future buyers. 
Table 1. A Contrast of moves between the English and Indonesian batik sales promotion letters

\begin{tabular}{|c|c|}
\hline Moves of English Sales Promotion Letter & Moves of Indonesian Batik Sales Promotion Letter \\
\hline 1. Establishing Credentials & 1. Introducing the Offer: \\
\hline 2. Introducing the Offer: & a. Offering the Batik Product \\
\hline a. Offering the product/service & Essential Detailing of the Batik \\
\hline b. Essential detailing of product/service & Product \\
\hline c. Indicating value of product/ service & Preclosing \\
\hline 3. Offering Incentives & Eliciting Interest \\
\hline 4. Enclosing Documents & Soliciting Response \\
\hline 5. Soliciting Response & Ending Politely \\
\hline 6. Using Pressure Tactics & \\
\hline 7. Ending Politely & \\
\hline
\end{tabular}

The rhetorical move of offering incentives is done informally in informal meetings conducted between the potential customer and representatives of the batik company. This bargaining process seems to show double standards of business practice in which the price could be negotiated by both parties for a win-win situation. The seller will lead the negotiation for a product purchase at a reasonable price whereas the potential buyers will take the negotiation towards the direction of getting the best quality of products at a relatively affordable price. In summary, offering incentives in the batik business belongs to the zone of informal negotiation and would most probably not appear in print. Two reasons could explain why offering incentives is conducted informally. First, the cultural belief that informal exchange provides more honest information about the customers and their expectations. Secondly, the final price should be put in writing only when different views and expectations between both parties are agreed upon. Consequently, there would probably be two different versions of the price of batik products, the informal and the formal. Although the foremost intention of any kind of business is making profit, with the strong influence of the Javanese culture, the genuine intention of creating the profit has been made less explicit under a more social and cultural preservation orientation (Purwadi, 2005).

Kristina and Mugijatna's (2005) assumption that the printed promotion of batik in Indonesia tends to inform rather than persuade their audience to buy the products has its merits. Two indications support this notion. First, the findings from the move analysis of batik SPLs suggest that establishing credentials does not exist in this business document. The batik company does not show the need of employing the move of establishing credentials in the SPLs. Instead, they directly go to the move of introducing the offer with the steps offering the product and essential detailing of the product. Interviews with the sales and marketing managers of batik industries revealed that before an SPL was written, some preliminary steps were taken. The initial steps could be performing surveys of prospective customers' needs, or taking informal approaches. Presumably the move of establishing credentials have taken place during the informal approaches. The batik company does not feel the need to include it in written form because there is a mutual understanding regarding the reputation of the company and its products between the batik company and the potential buyer. Secondly, the sales promotion letters of batik in question did not have the moves of offering incentives and using pressure tactics. Rather, they used the move of eliciting response which is less direct compared to that of the English version. Finally, the profit taking and profit making orientation was disguised under the expression of 'Semoga dapat menjadikan bahan pertimbangan (bagi Bapak)' - We do hope that this offer will be taken into consideration.

Are the Indonesian companies of batik not serious about selling their products by not expressing the persuasion explicitly? A high-context culture like Javanese prefers indirectness. Therefore, they expect the potential buyers to read between the lines on the real intention of the sales person because they believe that profit making when it is done directly is considered culturally unacceptable. Most Javanese people believe in making profit and building social relations simultaneously (Purwadi, 2005).

The texts of SPLs of batik used in this study were produced by the batik industries only when the potential buyers showed their inclination to buy the products. Consequently, the SPLs were considered confidential to outsiders unless specific permission was granted. Thus, the SPLs of batik in Indonesia are different from the ones mentioned by Bhatia (1993) in terms of their access-ability by the general publics.

However, the CPs of batik have five core rhetorical moves, namely establishing credentials, describing the business, describing the products, justifying the business, and soliciting response.

Important issues to be considered when establishing credentials include claims of moral obligation to preserve culture through batik making, description of history, modernization in batik making processes, statement of vision and mission, organizational structure and achievements. To realize the move establishing credentials, which affiliates with showing moral obligation and positioning of the company as a Javanese cultural 
hero, the writers employed seven steps. Every step was highlighted by a specific word representing an active process, such as 'melestarikan' (to preserve), mencurahkan (to dedicate), and the highest level of modality to signal obligation of the community 'harus terus dilestarikan keberadaannya' (has to be preserved continually). Establishing credentials on moral obligation to preserve culture normally occupies the first position in the $\mathrm{CP}$ of batik. It functions to build mutual perception between writers and readers and to prepare readers for further details in the $\mathrm{CP}$.

When realizing the step stating history in the move establishing credentials linguistically, the writers used specific words such as 'mendirikan' (to start business) or 'berdiri' (was founded). However, the subsequent step of widening access in the move of establishing credentials employed a metaphor of personification 'melebarkan sayap usahanya' ('to spread the wings of the business') to intensify the image of progressive movement from its headquarter in Solo, Central Java, to the capital city of Jakarta and other big cities in Indonesia.

In terms of using historical narration or historical background to establish credentials, findings of the present study support the work done by Osman (2005) on university brochures. Osman reported that the university brochures she studied use historical background to realize the move of establishing credentials. The rhetorical components of historical background used were the dates and reasons of university establishment.

When highlighting the vision of the company, writers of batik CP make use of expressions like 'memiliki masa depan cerah dalam industri batik' (is heading for a bright future in the batik industry). Likewise, the description of mission was realized into an active process such as 'menembus pasar manca negara' (to enter overseas market).

Claims of success are normally significant components in a description of business in a $\mathrm{CP}$ of batik. Claim of success are presented by exposing a series of efforts performed continuously. That process of being was realized linguistically in Indonesian into 'telah menjadi perusahaan manufaktur batik yang terpadu, yang telah dikenal sebagai produsen kain batik yang halus dan bermutu tinggi' (has become the integrated batik manufacturer, widely known as the producer of fine and high quality batik fabrics). A specific adjunct of time 'telah' (has) indicates the ability to reach a specific stage in the long process of perseverance, while a claim of excellence was stated by a superlative form 'terkemuka' (prominent) in Indonesian. The move describing the business would likely occupy second position after establishing credentials.

Defining the product as a component of the move describing the products in a $\mathrm{CP}$ of batik is interesting because it employed certain formulaic expressions of 'Istilah batik tradisional digunakan untuk menyebut...' (Traditional batik refers to...) or 'Seni membatik adalah...' ('The art of batik is...'). These formulaic expressions are also found in other Indonesian texts. Describing the products tends to occupy the middle position just before justifying the business and after describing the business. This move is the incorporation and extension of the step essential detailing of products in the SPL of batik.

The next obligatory move in a $\mathrm{CP}$ of batik is justifying the business. It is positioned at the end of a $\mathrm{CP}$ of batik, right before soliciting response. In order to show commitment to environmental preservation, a specific discourse marker was employed like 'demi' (for the sake of) in a formulaic expression of 'demi kelancaran proses pengembangan yang dilakukan secara berkesinambungan...' ('For the sake of gaining a simultaneous, better development...'). A commitment to capacity development was realized linguistically into 'terus menerus ditingkatkan' (continually developing). Likewise, a claim of high productivity was indicated by a typical expression 'mampu menghasilkan' (is capable to yield) and 'mampu memproduksi' ('is able to produce'). When showing a stage of development, a specific word is used to signal an extraordinary success 'merajai' (dominated) in an expression of 'Ekspor $\mathrm{BDH}$ sempat merajai pasar Australia selama 19771985...' ('BDH's export dominated the Australian market between 1977 and 1985).

Conversely, a claim of professionalism was expressed through specific vocabularies indicating a state of having such as 'memiliki 90 orang karyawan terlatih dan berpengalaman' ('employs 90 skilled and experienced workers').

The last rhetorical move of the $\mathrm{CP}$ of batik was soliciting response. Its function is to elicit future buyer's response through a follow-up contact for a future mutual benefiting cooperation. The move provides a more personal opportunity of accessibility regardless of geographical location. The concrete realization of the move was in the forms of addresses, telephone numbers, e-mail addresses, blogs or tweets.

Some notable conventions of batik company profiles can be explained as follows. Establishing credentials seems to be the most important component of a batik company profile in which the writers of the batik profiles try to present themselves to the potential buyers. Building credibility is therefore the core notion of the rhetorical move of establishing credentials. Relevant issues utilized in establishing credentials are the roles of the batik companies as preservers of culture, their moral obligation to keep the batik business running, their long existence in the batik making business, modernization and achievements.

Considering the position of this rhetorical move, establishing credentials usually occupies the 
initial position and becomes the entry gate to lead readers into the world of batik making industry, their visions and missions, producing capacity, reputation and achievements. These efforts are meant as the bridging behavior to lead the potential buyers to purchase batik in great numbers.

Describing the business rarely occupies the initial position in a company profile. It takes the second position after the move of establishing credentials. Since a substantial description of a business assists to establish trust, it significantly supports the function of a company profile as an image building business document.

Describing the products is another essential move in a company profile of batik. This move is an extension of the rhetorical move of describing the products in the sales promotion letters of batik. This phenomenon is an evidence of intertextuality in the sub-genre of batik promotion, a notion introduced by Bakhtin (1986). According to Devitt (1991), this transformation is called generic intertextuality or replication of rhetorical structure in which a writer uses earlier generic forms, linguistic and rhetorical features associated with the genre. The step of essential detailing of the product in the sales promotion letter of batik is transformed and embedded in the move of describing products in the company profile of batik, and thus shows the idea of being dynamic. Since there is a process of extension and elaboration here, it complies with the argument made by Devitt (1991) that genre is dynamic due to its recurring situations and its readiness to response to social phenomenon. In the perspective of the genre set in the sub-genre of batik promotion, the recurring situation is where writers of both texts attempt to change the potential buyer's behavior from half- inclined into the inclined and getting ready for batik purchase. In terms of position, the move of describing products normally occupies the middle position in a company profile of batik.

Justifying the business is another move that presumably follows the previous moves of describing the business and describing the products. Otherwise, the description of batik business and products sounds too subjective. The core issues that set the move of justifying the business relate to the claims of high capacity and productivity. According to Bandura (1986), perception of capacity and efficacy provides a powerful motivational impetus to organizational members, including potential buyers.

Table 2 Structure of the moves in BS and BDH company profiles

\begin{tabular}{ll}
\hline \multicolumn{1}{c}{ Moves Structure of CP (BS) } & \multicolumn{1}{c}{ Moves Structure of CP (BDH) } \\
\hline Describing the Business (A) & Establishing Credentials (A1) \\
Establishing Credentials (B1) & Describing Business (B) \\
Describing the Hand-made Batik Products (C1) & Setting History of Batik in Indonesia (C) \\
Describing the Hand-made BatikProducts (C2) & Classifying Batik (D) \\
Justifying the Business (D) & Identifying Influences on Javanese Batik (E) \\
Soliciting Response (E) & Establishing Credentials (A2) \\
Offering Collaboration & Establishing Credentials (A3) \\
& Describing the Products (F) \\
& Setting the Work Ethics (G) \\
& Justifying the Business (H1) \\
& Justifying the Business (H2) \\
& Establishing Credentials (A4) \\
& Establishing Credentials (A5) \\
& Soliciting Response (I) \\
\hline
\end{tabular}

Soliciting response seems to be obligatory in a $\mathrm{CP}$ of batik as it is the most prominent selling effort. This rhetorical move consists of a list of contact addresses and telephone numbers to provide accessibility for potential buyers. This rhetorical move is probably placed at the end of the batik profiles since it is the last stage that readers of the profiles complete reading the text. When potential buyers have a good impression, they would probably purchase the batik products in big numbers.

Among these five core moves, establishing credentials is the most prominent component in a batik company profile. It has various forms of expression ranging from showing moral obligation and claim of contribution in the process of cultural preservation to highlighting the organizational structure of the company. Table 4.2 presents the structure of the moves found in $\mathrm{BS}$ and $\mathrm{BDH}$ company profiles.

The discussion above has exhibited how writers of batik SPLs and CPs innovate conventions of writing both business documents in Indonesian language. These documents capture the integrated ideas of process, product, purposes, and participants in genre construction as suggested by Bhatia (1999).

Although the sub-genres of batik sales promotion letters and company profiles have their own conventions, awareness on the dynamic nature of any kind of genres (Bhatia, 2002) should be observed as stated by Miller (1994:163), that "genres change, evolve, and decay".

According to Hunston (1993), the ideology within which a text is written constrains choices in 
discourse organization, grammar and lexis. Therefore, writers from different cultures can potentially write texts with different rhetorical structures. Likewise, Golebiowski (1997:70) reminds us that writing is an 'expression of culture and the native culture, in the educational system of the writer's culture, influences his/her writing habits'.

Batik products produced by batik industries in Solo City are close to batik products from other places in Indonesia. However, Daryono and Wahyudi (2008:192) believe that batik and batik products of Solo have philosophical distinctive motifs and styles, which affect the way management promotes them in written form. The persuasive appeals used by the companies of batik are named credibility appeals (Connor \& Lauer, 1988), which refers to shared perceptions. These shared perceptions converge on the preservation of culture through batik.

Potential buyers as readers of promotional texts are central to writers. Aspects of persuasion should be explored by writers to motivate readers to purchase. Bakhtin (1986:95) refers to a genre's quality of being directed to someone as the notion of addressivity. The writer of a genre should consider his audience in selecting features of language in terms of lexicology, semantic, and syntax (Thompson \& Tribble, 2001; Hyland, 1999).

The chemistry between writers and readers of sales promotion letters and company profiles of batik producers creates a strong ground for mutual understanding and thus paves the way to purchase. Johns (1997) supported the idea that shared knowledge between readers and writers about the content as well as the form of a text is believed to be crucial for the success of text comprehension. Fulfillment of expectations of the potential batik buyer in this study was reflected by the freedom to choose any products preferred. These promotional documents motivated the future buyer to buy these batik products.

The success of the CP and SPLs of batik to fulfill the expectations of the potential buyer was mainly because of their self-contained content. Writers of the two business documents predicted buyer's expectations by including relevant details. The CP of batik impressed the buyer by including a prologue that refers to the motivation and philosophy of the company, kinds of products, motifs, lists of branches and representatives, and an offer for collaboration.

\section{CONCLUSION}

This study has provided evidence that to explicate the sub genres of SPLs and CPs batik, a researcher needs to consider the texts as products as well as processes. As a product, sales promotion letters and company profiles of batik construct a genre set in the sub-genre of batik promotion. In terms of process there was a shared knowledge of functions of CPs and SPLs of batik between readers and producers of the texts.

Although stability is needed to capture the underlying notions of a genre, a substantial amount of knowledge and awareness on how genre recurs as an indication of its dynamic trait, should be noted. The dynamic notion of genre may take the form of an extension or embeddedness. Consequently, scrutinizing a text in the constellation of other genres would likely be impossible to do unless someone is looking at other surrounding texts under the same colony of genre. Regarding the case of SPLs and CPs of batik, dynamism is realized through the extension of essential detailing product into describing product of batik.

Besides, this study has shown how the wider culture and that of the discourse community contribute to the form of SPLs and CPs of batik. An example would be the unavailability of the move using pressure tactics in the SPL of batik. Instead, offering incentives and using pressure tactics were addressed informally in separate meetings prior to batik purchase.

Regarding SPLs and CPs of batik, a question may arise on the importance of persuading prospective buyers based on current practices. So far, persuasion and pressure tactics to buy a product of batik through an SPL are carried out in an indirect style at the price of losing profit making opportunities in a competitive global market. Likewise, if producers of CPs of batik are to attract potential foreign buyers in a direct selling, without any intermediaries, the documents should highlight product details and product capacity as these two issues are the ones sought by potential foreign buyers.

On the contrary, persuading potential foreign buyers using a more aggressive manner may mean losing one's native cultural identity. This is a fundamental question which should have been addressed when the China-Asia Free Trade Agreement (CAFTA) was officially implemented at the beginning of last year.

\section{REFERENCES}

Bakhtin, M. M. (1986). Speech genres and other late essays. Austin: University of Texas Press.

Bandura, A. (1986). Social foundation of thought and action: A social cognitive theory. Englewood Cliffs., N.Y.: Prentice Hall.

Barron, A. (2006). Understanding spam: A macrotextual analysis. Journal of Pragmatics, 38, 880-904.

Bhatia, V. K. (1993). Simplification vs easyfication: the case of legal texts. Applied Linguistics, 4(1), 42-54. 
Bhatia, V. K. (1999). Integrating products, processes, purposes and participants in professional writing. In C.N. Candlin and K. Hyland (Eds.), Writing: Texts, processes and practice (pp. 21-39). London: Longman.

Bhatia, V. K. (2002). Generic view of academic discourse. In J. Flowerdew (Ed.), Academic discourse (pp. 21-39). London: Pearson Education.

Bhatia, V. K. (2004). World of written discourse: a genre based view. Advances in Applied Linguistics. London: Sage Publication.

Berkenkotter, C., \& Huckin, T. N. (1995). Genre knowledge in disciplinary communication: Cognition/culture/power. New Jersey: Lawrence Erlbaum Associate Publisher.

Cheung, M. (2006). A discourse analysis of Chinese and English sales letters in Hong Kong. Retrieved on September 23, 2010 from http://www.unizar.es/aelfe.

Connor, U., \& Lauer, J. (1988). Cross-cultural variation in persuasive student writing. In A.C. Purves (Ed.), Languages and cultures: Issues in contrastive rhetoric, (pp. 138-159). Newbury Park, CA: Sage.

Cotos, E., Huffman, S., \& Link, S. (2017). A move/step model for methods sections: Demonstrating rigour and credibility. English for Specific Purposes, 46, 90-106. doi: http://dx.doi.org/10.106/j.esp.2017.01.001.

Daryono, S., \& Wahyudi, M. (2008). Analisis kompetensi produk unggulan daerah pada batik tulis dan cap Solo di dati II kota Surakarta. Jurnal Ekonomi Pembangunan, 9(2), 184-197.

Devitt, A. (1991). Intertextuality in tax accounting: Generic, referential, and functional. In I. C. Bazerman \& J. Paradis (Eds.), Textual dynamics of the professions: Historical and contemporary studies of writing in professional communities (pp. 326-357). Madison: University of Wisconsin Press.

Geertz, C. (1973). Penjaja dan raja: Perobahan sosial dan modernisasi ekonomi di dua kota Indonesia. Jakarta: PT Badan Penerbit Indonesia Raya.

Golebiowski, Z. (1997). The structure of academic prose: a comparative study (Academic literacy across disciplines and cultures). Melbourne: Victoria University of Technology.

Grabe, W., \& Kaplan, R. B. (1996). Theory and practice of writing: An applied linguistic perspective. New York: Longman.

Hunston, S. (1993). Evaluation and ideology in scientific writing. In M. Ghadessy (Ed). Register analysis: Theory and practice (pp. 5773). London: Pinter Publisher.

Hyland, K. (1999). Talking to students: Metadiscourse in introductory course-books. English for Specific Purposes. 18(1), 3-26,
Jaworski, A., \& Coupland, N. (1999). The discourse reader. London: Routledge.

Johns, A. M. (1997). Text, role and context: Developing academic literacies. Cambridge: Cambridge University Press.

Jiang, F. K., \& Hyland, K. (2017). Metadiscursive nouns: Interaction and cohesion in abstract moves. English for Specific Purposes, 46, 114. Doi: http://dx/doi.org/10.16/j.esp.2016.11.001

Jolivet, E. R., \& Thomas, S. C. (2005). The rhetoric of conference presentation introductions: context, argument and interaction. International Journal of Applied Linguistics, 15(1), 45-71.

Kristina, D., \& Mugijatna. (2005). Bahasa Inggris pariwisata dalam brosur daerah tujuan wisata di Surakarta. Pusat Penelitian dan

Pengembangan Pariwisata, Lembaga Peneltian dan Pengabdian Pada Masyarakat. Surakarta: UNS.

Leitch, S., \& Palmer, I. (2010). Analysing texts in context: Current practices and new protocols for critical discourse analysis in organization studies. Journal of Management Studies, 47, 1194-1212.

Leki, I. (1991). Twenty five years of contrastive rhetoric: Text analysis and writing pedagogies. TESOL Quarterly, 25(1), 123-143.

Lieungnapar, A., Todd, R. W., \& Trakulkasemsuk, W. (2017). Genre induction from a linguistic approach. Indonesian Journal of Applied Linguistics, 6(2), 319-329. Doi: dx.doi.org/10.17509/ijal.v6i2.4917

Lillis, T. (2008). Ethnography as method, methodology, and deep theorizing. Journal of Written Communication, 25(3), 353-388.

Limaye, M. R. (1984). The syntax of persuasion: Two business letters of request. Journal of Business Communication, 20(2), 17-30.

Merriam, S. B. A. (2002). Qualitative research practice: Examples for discussion and analysis. San Francisco: Jossey-Bass.

Miller, C. R. (1994). Genre as social action. In A. Fredman \& P. Medway (Eds.), Genre and the new rhetoric (pp. 23-42). London: Taylor \& Francis Publisher.

Osman, H. (2005). Structural organization and socio-cognitive strategies in university brochures: Implications for ESP. (Doctoral dissertation). Universiti Malaya, Kuala Lumpur.

Parkinson, J. (2017). The student laboratory report genre: A genre analysis. English for Specific Purposes, 45, 1-13. Doi: http://dx.doi.org/10.1016/j.esp.2016.08001

Pare, A., \& Smart, G. (1994). Observing genres in action: Towards a research methodology. In A. Freedman \& P. Medway (Eds.), Genre in the New Rhetoric, 146-154. 
Purwadi. (2005). Kiat bisnis orang Jawa: Madhep ngalor sugih, madep ngidul sugih. Retrieved from www.budayajawa.com.

Safnil. (2000). Rhetorical structure analysis of the Indonesian research articles (Doctoral dissertation). Australian National University, Australia.
Seltzer, B., \& Sherwin, I. (1989). A comparison of clinical features in early and later onset primary degenerative dementia, one entity or two. Arch Neurol, 40(3):143-6.

Thompson, P \& Tribble, C. (2001). Looking at citations: Using corpora in English for Academic Purposes. Language Learning and Technology, 5(3): 91-105. 